\title{
REVISTA BRASILEIRA DE ENFERMAGEM: 70 ANOS
}

Joel Rolim Mancia ${ }^{1}$

Em maio de 2002 a REBEn, órgão de divulgação da Associação Brasileira de Enfermagem completou 70 anos.

O editorial Era Nova (1932), de Rachel Haddock Lobo (RHL), publicado no primeiro fascículo de Annaes de Enfermagem é visionário ao comentar que esta era a primeira revista da profissão e que se constituiria no "arauto" da enfermagem.

Cabe lembrar que RHL foi a primeira editora da revista e uma das fundadoras e graças à sua doação de papel foi possivel imprimir o número inicial da revista (CARVALHO, 1976).

Há controvérsias quanto a quem realmente foi responsável pela criação da REBEn. Carvalho (1976) relata depoimento de Edith de Magalhães Fraenkel (EMF) em que esta se intitula fundadora da revista e como prova expõe uma estatueta de bronze e mármore que havia ganho das enfermeiras por ocasião do lançamento do primeiro número de Annaes de Enfermagem. A estatueta tem escrito em sua base $-1^{\circ}$ Volume. É provável que muitas pessoas tenham contribuido para a consecução deste feito. No entanto, é inquestionável a participação de RHL e EMF, respectivamente diretora da Escola de Enfermagem Anna Nery e presidente da Associação Nacional de Enfermeiras Diplomadas Brasileiras (ANEDB), no ano de 1932.

Em sua trajetória a REBEn passou por muitas dificuldades, entre as quais a interrupção do periódico (1941), durante a Segunda Grande Guerra.

Em 1946, retorna à publicação e, em 1948, se inicia nova fase, quando registra sua ficha catalográfica como v. 1, n. 1 e obtém o registro de publicação seriada (ISSN). Neste momento, a editorialista solicita que sejam enviados artigos "justamente para que a revista possa apresentar problemas de enfermagem relativos a todo o pais é que essa contribuição se torna imprescindivel" (ANAIS DE ENFERMAGEM, 1948, p. 1). Percebe-se que há uma reafirmação do compromisso da Associação de que a revista esteja divulgando a produção que interesse a toda a enfermagem brasileira e, ao mesmo tempo, que estas informações sejam abrangentes e geradas nos diversos estados do pais.

Em 1954, por determinação da Assembléia de Delegadas, a revista passa a se chamar Revista Brasileira de Enfermagem. O primeiro fascículo, além do novo nome e da nova capa, especialmente desenhada por artista plástico famoso (Santa Rosa), vem com a marca REBEn. Ao apresentar a nova revista a editorialista chama a atenção para a necessidade de dobrar o número de assinaturas.

Em 1962, Marina de Andrade Rezende, então presidente da ABEn, publicou editorial descrevendo a nova apresentação da revista que, naquela ocasião, comemorava 30 anos de circulação. Nesse editorial escreve as palavras que definiram o papel da REBEn, quais sejam: "estabelece-se para realizar comunicação, para servir de depositária das concepções que vão plasmando, moldando e dando existência à enfermagem nacional" (REVISTA BRASILEIRA DE ENFERMAGEM, 1962, p. 401). As mensagens veiculadas pela revista e oriundas da ABEn não estavam descoladas do cenário e nem das idéias que caracterizavam os atores da enfermagem, à época.

Através dos editoriais é possivel fazer uma crônica da enfermagem, visto que estes acompanham a trajetória da entidade na enunciação do discurso da enfermagem brasileira.

Proença (1992, p. 7) ao lembrar os 60 anos da REBEn diz: "historicamente, a nossa revista sempre se sustentou no desejo dos dirigentes e sócios da ABEn em manter o veículo oficial de divulgação", ao mesmo tempo que reverencia àqueles que contribuiram para a existência do periódico, não esquece de comentar os problemas crônicos que dificultam a distribuição regular da revista.

Nos últimos anos, como reflexo da nova forma de gestão da ABEn, foi possivel promover o aumento do número de assinantes e a captação de um maior número de artigos, o que determinou a regularidade na distribuição da revista.

Neste 2002, a REBEn chega à comunidade com novo formato, mais cores, melhor qualidade de papel e, principalmente, divulgando uma produção cientifica recente e atualizada.

Como órgão de divulgação da ABEn a revista tem o compromisso de estar explicitando em suas páginas o projeto político da Associação. No entanto, o uso deste espaço tem sido restrito e a entidade tem se manifestado através do Informativo ABEn, o que parece mais apropriado, por ter uma distribuição mais rápida e atingir um universo muito mais amplo. Entretanto, os grandes acontecimentos da enfermagem têm sido registrados nos editoriais.

\footnotetext{
1 Editor
} 
Ainda, nesta perspectiva, a Revista Brasileira de Enfermagem tem realizado nos últimos cinco anos o Encontro Nacional de Editores de Periódicos de Enfermagem - ENEPEn, evento que se inseriu na agenda da ABEn e acontece, anualmente, durante o Congresso Brasileiro de Enfermagem. O propósito do Encontro é de contribuir para a qualificação das revistas de enfermagem, o que tem se concretizado, plenamente, através das discussões de temas e definição de propostas como formação de rede de periódicos, diagnóstico das publicações de enfermagem no Brasil e avaliação da produção científica submetida à publicação. A crescente participação de editores e a presença de autoridades da área de financiamento demonstram que ao se preocupar com esta questão a ABEn responde a uma necessidade da comunidade científica.

São setenta anos como referência na construção e divulgação do conhecimento da enfermagem.

É um longo caminho percorrido. Inúmeras enfermeiras ajudaram a demarcar esse caminho: homenagem a todas que a tornaram grande e respeitada.

\section{REFERÊNCIAS BIBLIOGRÁFICAS}

ANAIS DE ENFERMAGEM. Editorial. Rio de Janeiro: ABEn. v. 1, n. 1, p. 1, janeiro de 1948.

CARVAlHO, A. C. de. Associação Brasileira de Enfermagem: 1926-1976 documentário. ABEn: Brasilia, 1976.

LOBO, R. H. Era Nova. Annaes de Enfermagem, v. 1, p. 1, maio. 1932. Editorial.

PROENÇA, J. da F. Revista Brasileira de Enfermagem - 60anos de existência. Rev. Bras. Enferm., v. 45, n. 1, p. 1, jan./ mar. 1992. Editorial.

REVISTA BRASILEIRA DE ENFERMAGEM. Editorial. Braspilia: ABEn, ano 15, n. 5, p. 401-402, out. 1962. 